\title{
Tracking Amazonian cheese microbial diversity: Development of an original, sustainable, and robust starter by freeze drying/spray drying
}

\author{
A. A. Ferreira, ${ }^{*}$ S. Huang, $† \ddagger$ Í.T. Perrone, ${ }^{*}$ P. Schuck, $¥ \S$ G. Jan, $₫ \S$ and A. F. Carvalho*1 \\ *Inovaleite Laboratory, Department of Food Technology, University Federal of Viçosa, 36570-000 Viçosa, Brazil \\ †Suzhou Key Laboratory of Green Chemical Engineering, School of Chemical and Environmental Engineering, College of Chemistry, \\ Chemical Engineering and Material Science, Soochow University, 215123 Jiangsu, China \\ fINRA, UMR1253 STLO, Science et Technologie du Lait et de l'OEuf, 35000 Rennes, France \\ §Agrocampus Ouest, UMR1253 STLO, 35000 Rennes, France
}

\section{ABSTRACT}

Marajó cheese made with raw buffalo milk in the Amazon region of Brazil can be considered a good source of wild lactic acid bacteria strains with unexplored and promising characteristics. The aim of this study was to develop a potential probiotic starter culture for industrial applications using freeze drying and spray drying. A decrease in the survival rates of freezedried samples compared with spray-dried samples was noted. The spray-dried cultures remained approximately $10^{9} \mathrm{cfu} \cdot \mathrm{g}^{-1}$, whereas the freeze-dried samples showed $10^{7} \mathrm{cfu} \cdot \mathrm{g}^{-1}$ after $60 \mathrm{~d}$ of storage at $4^{\circ} \mathrm{C}$. All of the spray-dried samples showed a greater ability to decrease the $\mathrm{pH}$ in $10 \%$ skim milk over $24 \mathrm{~h}$ compared with the freeze-dried samples. The spray-dried samples showed a greater resistance to acidic conditions and to the presence of bile salts. In addition, under heat stress conditions, reduction was under 2 log cycles in all samples. Although the survival rate was similar among the evaluated samples after drying, the technological performance for skim milk showed some differences. This study may direct further investigations into how to preserve lactic acid bacteria probiotics to produce spray-dried starters that have a high number of viable cells that can then be used for industrial applications in a cost-effective way.

Key words: Lactobacillus plantarum, probiotic, sweet whey, Amazonian artisanal cheese

\section{INTRODUCTION}

In the food industry, starter or adjunct cultures are obtained by 2 methods of concentration and preservation: cultures obtained in frozen conditions and cultures

Received December 7, 2016.

Accepted May 27, 2017.

${ }^{1}$ Corresponding author: antoniofernandes@ufv.br obtained in a dried form, such as freeze drying. The major disadvantage to using frozen cultures is the cost of transport, storage, and manipulation (Carvalho et al., 2004b; Santivarangkna et al., 2007). Dried preparations have the added advantage of long-term preservation and handling and storage convenience. Freeze drying is a widespread technique; a large number of freeze-dried cultures are commercially available (Santivarangkna et al., 2007), These are widely used in the implementation of lactic acid bacteria (LAB) cultures (To and Etzel, 1997; Madhu et al., 2011; Kandil and El Soda, 2015).

Nevertheless, the freeze-drying process is expensive and complex, and can take days to complete for large product loads due to the slow energy and water transfer needed to dry the material. This, as well as the growing commercial interest in microbial culture starters, explains continuing research to develop alternative drying techniques (Carvalho et al., 2004b; Morgan et al., 2006; Santivarangkna et al., 2007; Silva et al., 2011).

Spray drying is a good example of a commonly used technique in industrial food drying today, which can also be used for drying bacteria. The energetic cost of spray drying is approximately 10 times less than that of freeze drying. The versatility of the process and the considerable progress made through technical innovation have led to greater flexibility in meeting biotechnological requirements, especially low-heat treatments that help avoid loss of activity (Schuck et al., 2013).

Maximizing the survival of LAB cultures during drying and ensuring subsequent storage conditions for long periods is essential to maintaining technological characteristics and economic viability. The biological activity of a lactic culture that includes cell viability and its physiological state is necessary to evaluate the quality of a starter culture (Peighambardoust et al., 2011). Microbial cell survival throughout drying and storage depends on many factors, including initial concentration of microorganisms, growth conditions, growth medium, drying medium, storage conditions, and rehydration conditions (Carvalho et al., 2003, 2004b). 
Even though freeze drying is the most common method used today, spray drying can also be used to dry probiotic cultures (Maciel et al., 2014; Soukoulis et al., 2014; Shokri et al., 2015; Utami et al., 2016). Probiotics are defined as "live microorganisms which when administered in adequate amounts confer a health benefit on the host" (FAO/WHO, 2001). However, these health benefits may depend on the viability of the probiotic cells and the maintenance of their probiotic properties in commercial cultures and food products during the storage (Rathnayaka, 2013).

The composition of the growth and drying medium can influence the protection during storage of dried cells (Carvalho et al., 2003, 2004a). Skim milk powder has been selected as the drying medium for most LAB cultures. Skim milk helps avoid cellular injury by stabilizing the cell membrane constituents (Carvalho et al., 2004; Zamora et al., 2006; Maciel et al., 2014) and it is one of the media used for bacterial protection during drying (Fu and Chen, 2011).

Whey is a food byproduct of cheese manufacturing. The large amount of lactose and whey proteins in sweet whey make it an ideal medium for growing LAB (Huang et al., 2016). Moreover, several studies have demonstrated that milk components could have protective effects on probiotics in adverse stress conditions (Ananta et al., 2005; Huang and Chen, 2013; Huang et al., 2014, 2016; Maciel et al., 2014).

Therefore, the use of a nutritional and low-cost drying medium that maintains the viability and functional properties of LAB cultures during storage, in association with a low-cost drying technology, can promote the development of an optimal probiotic or starter culture for industrial application (Maciel et al., 2014).

The use of wild strains is promising for starter or adjunct culture production because they contain characteristics that are particularly desirable for the food industry. The biodiversity found in artisanal cheeses allows for the identification of microbial strains with a wide range of technological and probiotic characteristics (Randazzo et al., 2007, 2009; Van Hoorde et al., 2008; Terzic-Vidojevic et al., 2014; de Freitas et al., 2015; Castro et al., 2016).

Brazil stands out in the production of artisanal buffalo milk cheese on the island of Marajó, in the state of Pará, located in the Amazon region. This cheese is known as Marajó cheese. The curd coagulation of Marajó is caused only by the autochthonous microbiota in raw milk and in the processing environment, which makes it a characteristic product of the region. Consequently, this cheese can be considered as a good source for isolating of the wild LAB strains for industrial application.
The aim of this study was to develop a potential probiotic starter culture for industrial applications using freeze drying and spray drying.

\section{MATERIALS AND METHODS}

\section{Bacterial Strain and Growth Conditions}

The strain Lactobacillus plantarum UFV-Lb26 isolated from Marajó cheese and present in the culture collection of the INOVALEITE Laboratory, Department of Food Technology of the University Federal of Viçosa, Brazil, was selected to study the effects of freeze drying and spray drying. This strain exhibits the ability to produce diacetyl, as well as proteolitic activity, an acidifying and antimicrobial activity that attacks foodborne pathogens, Staphylococcus aureus ATCC 25923 and Listeria monocytogenes ATCC 7644 (data not shown), in addition to providing potential probiotic qualities such as low $\mathrm{pH}$ tolerance and high bile salt concentration of up to $1 \%$. The strain was preserved at $-20^{\circ} \mathrm{C}$ in Eppendorf tubes containing de Man, Rogosa, and Sharpe broth (MRS, Difco, Bordeaux, France) with $30 \%$ (vol/vol) glycerol added.

\section{Preparation of Cells for Drying Experiments}

The frozen culture $\left(-20^{\circ} \mathrm{C}\right)$ was grown in $10 \mathrm{~mL}$ of sterilized Lactobacilli MRS broth at $30^{\circ} \mathrm{C}$ for $18 \mathrm{~h}$ (stationary phase). A $1 \%$ aliquot of the grown culture was transferred and regrown under the same conditions. A cell density of approximately $10^{9} \mathrm{cfu} \cdot \mathrm{mL}^{-1}$ was obtained after incubation.

The cultures were transferred under aseptic conditions into 1-mL sterile Eppendorf tubes for the freezedrying process, and into 1-L sterile centrifuge tubes for the spray-drying process. Next, the cultures were centrifuged at $8,000 \times g$ for $5 \mathrm{~min}$ at $4^{\circ} \mathrm{C}$. The supernatant was discarded and the harvested cells, in the form of pellets, were washed once using PBS at $\mathrm{pH}$ 7.0 (PBS, Difco, France). The cell suspensions were centrifuged again as previously. After discarding the supernatant, the pellets were suspended separately into the drying carrier medium with enhanced high DM, that is, 20\% (wt/vol) of reconstituted skim milk powder (RSM; Lactalis, Bourgbarré, France), reconstituted sweet whey powder (RSW; Lactalis), and reconstituted sweet whey permeate powder (RSWP; Lactalis). The RSM contains all the components of milk in this composition, except for fat: whey proteins, lactose, vitamins, and minerals. While RSWP has no significant amount of protein, it does contain lactose, vitamins, and minerals. 
Freeze Drying. The cell suspensions resuspended $\left(10^{9} \mathrm{cfu} \cdot \mathrm{mL}^{-1}\right)$ in the drying carrier medium, as described in the Preparation of Cells for Drying Experiments, were frozen at $-20^{\circ} \mathrm{C}$ for $24 \mathrm{~h}$, and then freezedried (S.G.D. SERAIL, France) for 24 h. The samples end temperatures were $25^{\circ} \mathrm{C}$. For post-drying experiments, the freeze-dried powder samples were stored at $4^{\circ} \mathrm{C}$ in closed safe-lock Eppendorf tubes for $60 \mathrm{~d}$. Small amounts of powder (approximately $1 \mathrm{~g}$ ) were subjected to rehydration and viability enumeration.

Spray Drying. Dried samples consisted of 1-L samples of fresh cultures, resuspended $\left(10^{9} \mathrm{cfu} \cdot \mathrm{mL}^{-1}\right)$ in carrier medium with enhanced high DM [i.e., 20\% (wt/vol)] mentioned in Preparation of Cells for Drying Experiments. Such concentrations are widely used for spray drying and allow limited heating compared with unconcentrated milk or whey. The concentrated microbial suspensions were spray dried in a pilot-scale Mobile Minor spray-dryer (GEA Niro A/S, Copenhagen, Denmark) as previously described (Huang et al., 2016). A 2-fluid spray nozzle with an orifice diameter of $0.8 \mathrm{~mm}$ was used.

The outlet spray drying temperatures were $75^{\circ} \mathrm{C}$ with inlet temperatures fixed at $180^{\circ} \mathrm{C}$. The experiments were carried out in triplicate. The feed rate was maintained at around $30 \mathrm{~mL} \cdot \mathrm{min}^{-1}$ to obtain the outlet air relative humidity at $10 \pm 1 \%$ for all the samples. For the postdrying experiments, spray-dried powders were stored in plastic bags under vacuum at 4 and $20^{\circ} \mathrm{C}$, respectively. Small amounts of powder (approximately $1 \mathrm{~g}$ ) were subjected to rehydration and viability enumeration.

\section{Enumeration of the Bacteria}

The freeze-dried and spray-dried powders were rehydrated in sterile tryptone water (sodium chloride 5 $\mathrm{g} \cdot \mathrm{L}^{-1}$ and tryptic hydrolysate of casein $10 \mathrm{~g} \cdot \mathrm{L}^{-1}$ ) to the same solid content as the original suspension. The rehydrated samples were kept at room temperature for $30 \mathrm{~min}$ to allow complete rehydration. The count of colony-forming units was carried out in triplicate before the freeze drying/spray drying, then after the freeze drying/spray drying (time 0 ), at 7,30 , and $60 \mathrm{~d}$ of storage at $4^{\circ} \mathrm{C}$.

The resulting samples were subjected to serial dilutions using tryptone water. Each dilution was pour plated onto an MRS agar (Difco) and the plates were incubated at $30^{\circ} \mathrm{C}$ for $48 \mathrm{~h}$. Enumeration of the bacteria was performed in triplicate and the total counts of the viable bacteria were expressed in log colony-forming units per gram of powder $\left(\mathrm{cfu} \cdot \mathrm{g}^{-1}\right)$. The viability of bacteria after freeze drying and spray drying (\%) was calculated according to

$$
\text { Viability }=\log \mathrm{N} / \log \mathrm{N}_{0} \times 100,
$$

where $\mathrm{N}$ refers to the bacteria population $\left(\mathrm{cfu} \cdot \mathrm{g}^{-1}\right)$ in powders after freeze drying $(0,7,30$, and $60 \mathrm{~d})$ and spray drying $(0,7,30$, and $60 \mathrm{~d}) ; \mathrm{N}_{0}$ refers to the initial population $\left(\mathrm{cfu} \cdot \mathrm{g}^{-1}\right)$ before drying.

\section{Acidifying Activity}

The acidifying activity was performed to evaluate the biological activity of freeze-dried and spray-dried L. plantarum cells in $10 \%$ reconstituted skim milk. An acidifying activity of a lactic acid starter that includes cell viability and physiological state is needed to evaluate the starter quality. Biological activity is defined as the ability of a lactic acid starter to acidify a certain medium (Peighambardoust et al., 2011).

The freeze-dried and spray-dried samples in time 0 were reconstituted in tryptone water and $1 \mathrm{~mL}$ of the culture was added separately to $100 \mathrm{~mL}$ of reconstituted skim milk (RSM, Lactalis) 10\% (wt/vol). Then, acid production and acidification kinetics were evaluated by checking the $\mathrm{pH}$ with CINAC software (Wcinac $32 \mathrm{~V}$ 2.1, INRA, Rennes, France) during 24 h.

\section{Stress Conditions}

The freeze-dried and spray-dried cells at time 0 were subjected to stress conditions (acid stress, thermal stress, and bile salt stress) to assess their resistance and probiotic potential. Lactobacillus plantarum cells cultured in MRS broth were used as control.

In the acid stress conditions, freeze-dried and spraydried cells were resuspended for $30 \mathrm{~min}$ as described above in item 2.5 in tryptone water and centrifuged $\left(8,000 \times g\right.$ for $5 \mathrm{~min}$ at $\left.4^{\circ} \mathrm{C}\right)$. Next, the supernatant was discarded and the same volume of solution was added (sodium lactate $10 \mathrm{~g}$; tryptone $10 \mathrm{~g}$; yeast extract $10 \mathrm{~g}$; $+\mathrm{K}_{2} \mathrm{HPO}_{4}, 3 \mathrm{H}_{2} \mathrm{O} 2.5 \mathrm{~g} ; \mathrm{MnSO}_{4}, \mathrm{H}_{2} \mathrm{O} 5 \mathrm{mg}$ ) at $\mathrm{pH}$ 2.5. The monitoring of colony-forming units was performed in triplicate every $15 \mathrm{~min}$ for $1 \mathrm{~h}$.

Alternately, the same bacterial suspensions were subjected to thermal stress at $60^{\circ} \mathrm{C}$ in a water bath for 10 min. Bile salt stress was applied as described previously (Leverrier et al., 2003) by adding $1 \mathrm{~g} \cdot \mathrm{L}^{-1}$ bile salts to the suspensions for $1 \mathrm{~h}$.

\section{Powder Water Profile (Spray Drying)}

Water Content Measurements. The powders' water contents were tested according to the methods described by Schuck et al. (2012). The water content (Table 1) in the spray-dried samples was calculated as 
Table 1. Water profile in spray-dried culture powders in different media

\begin{tabular}{lcc}
\hline Medium $^{1}$ & Water content $(\%)$ & Water activity (-) \\
\hline RSM & $3.97 \pm 0.11$ & $0.18 \pm 0.01$ \\
RSW & $3.80 \pm 0.20$ & $0.17 \pm 0.03$ \\
RSWP & $3.10 \pm 0.44$ & $0.12 \pm 0.04$ \\
\hline
\end{tabular}

${ }^{1} \mathrm{RSM}=$ reconstituted skim milk powder; $\mathrm{RSW}=$ reconstituted sweet whey powder; RSWP = reconstituted sweet whey permeate powder.

follows: approximately $1 \mathrm{~g}$ of powder was spread on a Petri dish containing sand, then placed in the water content analyzer, which heated the powder up to $102 \pm$ $2^{\circ} \mathrm{C}$ until the mass equilibrated to a final value. Afterward, the Petri dish was weighed and the moisture was calculated by percentage. This analysis was conducted in duplicate.

Water Activity. Water activity was measured in triplicate with a Novasina water activity meter (RTD33 TH-2, Pfäffikon, Switzerland) at a constant temperature of $25^{\circ} \mathrm{C}$.

\section{Statistical Analysis}

The effects of the drying medium and the drying process on survival rate, acidifying activity, and stress conditions were evaluated by ANOVA and Tukey test $(P<0.05 ; P<0.01)$ for comparison.

\section{RESULTS}

\section{Effect of Freeze Drying and Spray Drying on Survival Rate}

Figure 1 shows the survival rate results of $L$. plantarum during the storage period $(0,7,30$, and $60 \mathrm{~d})$ at $4^{\circ} \mathrm{C}$ for both freeze-dried and spray-dried cultures. Before both drying processes, the viability of $L$. planta-

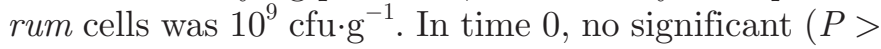
$0.05)$ loss of viability was observed for freeze-dried and spray-dried samples. However, there was a reduction of $1 \mathrm{log}$ cycle in the freeze-dried samples (RSW and RSWP). A decrease occurred in the survival rates of freeze-dried samples (RSW and RSWP) compared with all spray-dried samples after $60 \mathrm{~d}$ of storage, but this survival rate was similar in all samples. The spray-dried cultures remained approximately $10^{9} \mathrm{cfu} \cdot \mathrm{g}^{-1}$ after $60 \mathrm{~d}$ of storage at $4^{\circ} \mathrm{C}$, whereas the freeze-dried cultures had a reduction of $1 \mathrm{log}$ cycle in $\mathrm{RSM}\left(10^{8} \mathrm{cfu} \cdot \mathrm{g}^{-1}\right)$ and 2 log cycles in RSW $\left(10^{7} \mathrm{cfu} \cdot \mathrm{g}^{-1}\right)$ and RSWP $\left(10^{7} \mathrm{cfu} \cdot \mathrm{g}^{-1}\right)$ after $60 \mathrm{~d}$ of storage at $4^{\circ} \mathrm{C}$. No significant $(P>0.05)$ difference was observed between carrier mediums used for spray-dried cultures with regard to the survival rate of L. plantarum. The spray-dried culture stored at $20^{\circ} \mathrm{C}$ also maintained a survival rate at $10^{9} \mathrm{cfu} \cdot \mathrm{g}^{-1}$ during the 60 -d storage period (data not shown).

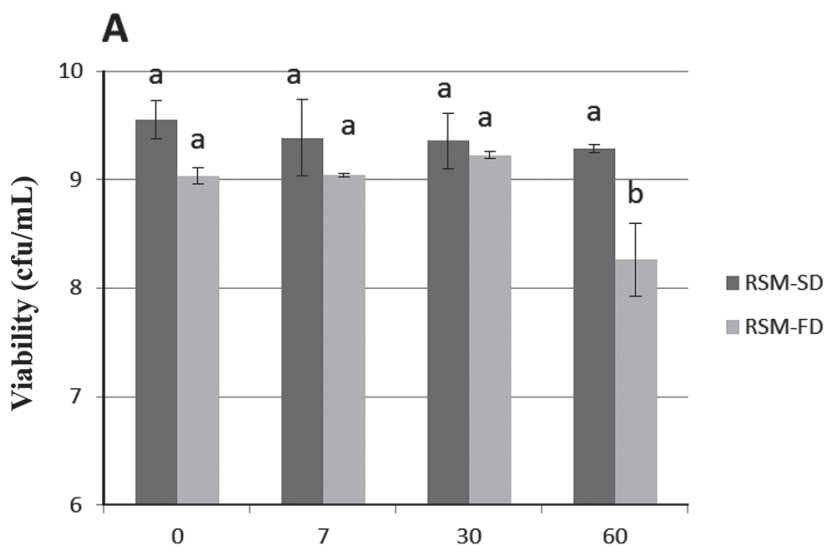

B
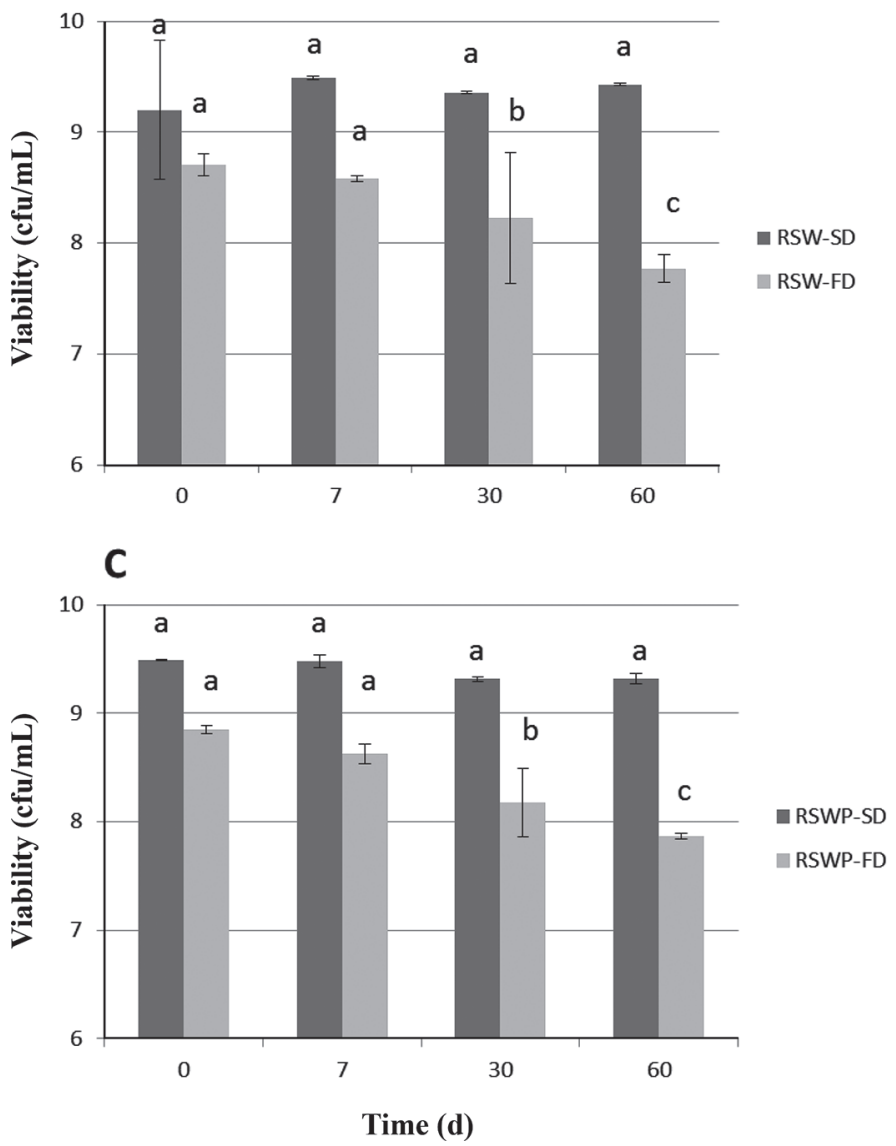

Figure 1. The survival rates of Lactobacillus plantarum on the first day and during the storage period $(7,30$, and $60 \mathrm{~d})$ at $4^{\circ} \mathrm{C}$ in triplicate. $\mathrm{SD}=$ spray drying; $\mathrm{FD}=$ freeze drying. (A) Drying samples in reconstituted skim milk (RSM), (B) drying samples in reconstituted sweet whey (RSW), (C) drying samples in reconstituted sweet whey permeate (RSWP). Different letters indicate a significant difference between bacteria populations $(P<0.05)$. Error bars represent SE. 


\section{Effect of Freeze Drying and Spray Drying on Acidifying Activity}

The biological activity of dried $L$. plantarum was monitored by testing the cells' ability to acidify $10 \%$ skim milk after freeze-drying and spray-drying processes. Although the survival rates of the L. plantarum cells subjected to freeze drying and spray drying were similar, their technological performances were different. Figure 2 shows the acidification kinetics results over $24 \mathrm{~h}$ for skim milk inoculated with freeze-dried and spray-dried cultures.

All spray-dried samples showed a greater ability to decrease the $\mathrm{pH}$ in $10 \%$ skim milk compared with the freeze-dried samples over the same period. The initial $\mathrm{pH}$ for both was approximately 6.5. The spray-dried samples in RSM (Figure 2A) showed a reduced $\mathrm{pH}$ level of 4.80 in $24 \mathrm{~h}$, whereas the RSW (Figure 2B) and RSWP (Figure 2C) samples showed a reduced $\mathrm{pH}$ level of 4.50. For the freeze-dried samples, reduction was not significant $(P>0.01)$ in the 3 samples evaluated: RSM (6.20), RSW (6.15), and RSWP (6.12). Finally, the spray-dried samples were significantly different $(P<$ 0.01) from the freeze-dried samples.

\section{Effect of Freeze Drying and Spray Drying on Stress Tolerance}

Figure 3 shows the effect of acid stress on L. plantarum viability for freeze-dried and spray-dried cultures in different mediums and for the cells cultured in MRS broth over $60 \mathrm{~min}$ of challenge at $\mathrm{pH}$ 2.5. The spraydried samples showed greater resistance under acid conditions. However, all freeze-dried samples showed low resistance at $\mathrm{pH} 2.5$, except for the freeze-dried cells in RSW, which reduced just 1 log cycle after 60 min. The freeze-dried cells in RSM reduced 4 log cycles and RSWP reduced 5 log cycles. Moreover, the cells cultured in MRS broth showed better resistance to acid conditions than the freeze-dried samples (Figure 3B).

The spray-dried cells in RSWP showed limited loss of viability (approximately 1 log cycle) compared with other spray-dried samples. This reduction was significant $(P<0.01)$, confirming the influence of different dairy matrices in the carrier medium on the survival rate of the cells. The freeze-dried samples also showed significant $(P<0.01)$ reduction between carrier media.

None of the samples evaluated showed significant $(P>0.01)$ viability loss in the presence of bile salts (Figure $4 \mathrm{~A}$ and $4 \mathrm{~B}$ ). In addition, under heat condition stress (Figure 5A and 5B), reduction was less than 2 log cycles in both freeze-dried and spray-dried samples. This reduction was significant $(P<0.01)$. The RSWP samples showed lower resistance under heat stress and significant $(P<0.01)$ viability loss in comparison with all the samples. Moreover, the cells cultured in MRS broth showed a better resistance under heat stress conditions than the freeze-dried and spray-dried samples drying in RSWP (Figure 5A and 5B).
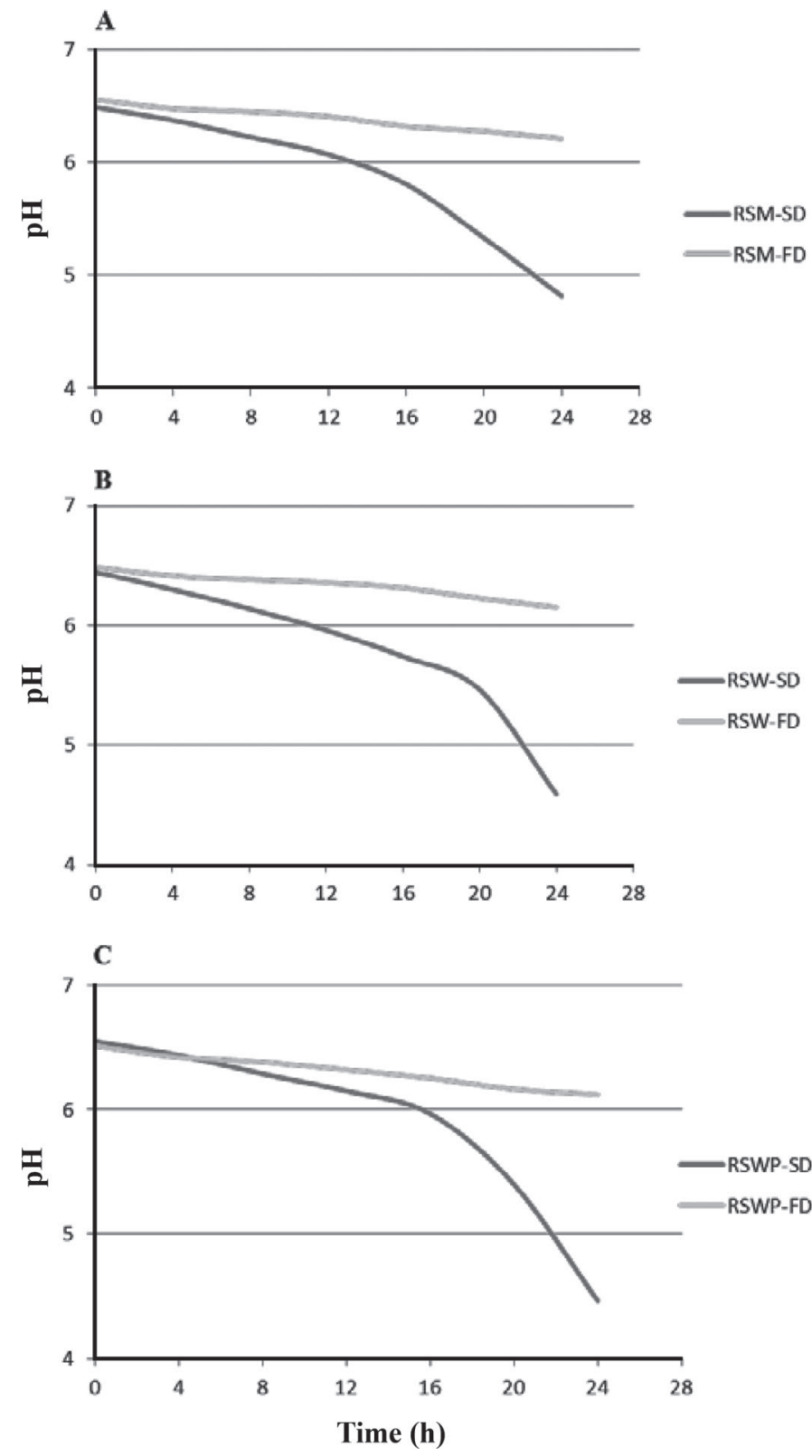

Figure 2. The acidification kinetics during $24 \mathrm{~h}$ of the skim milk inoculation with freeze-dried and spray-dried cultures. SD = spray drying; FD = freeze drying. (A) Samples dried in reconstituted skim milk (RSM), (B) samples dried in reconstituted sweet whey (RSW), (C) samples dried in reconstituted sweet whey permeate (RSWP). 


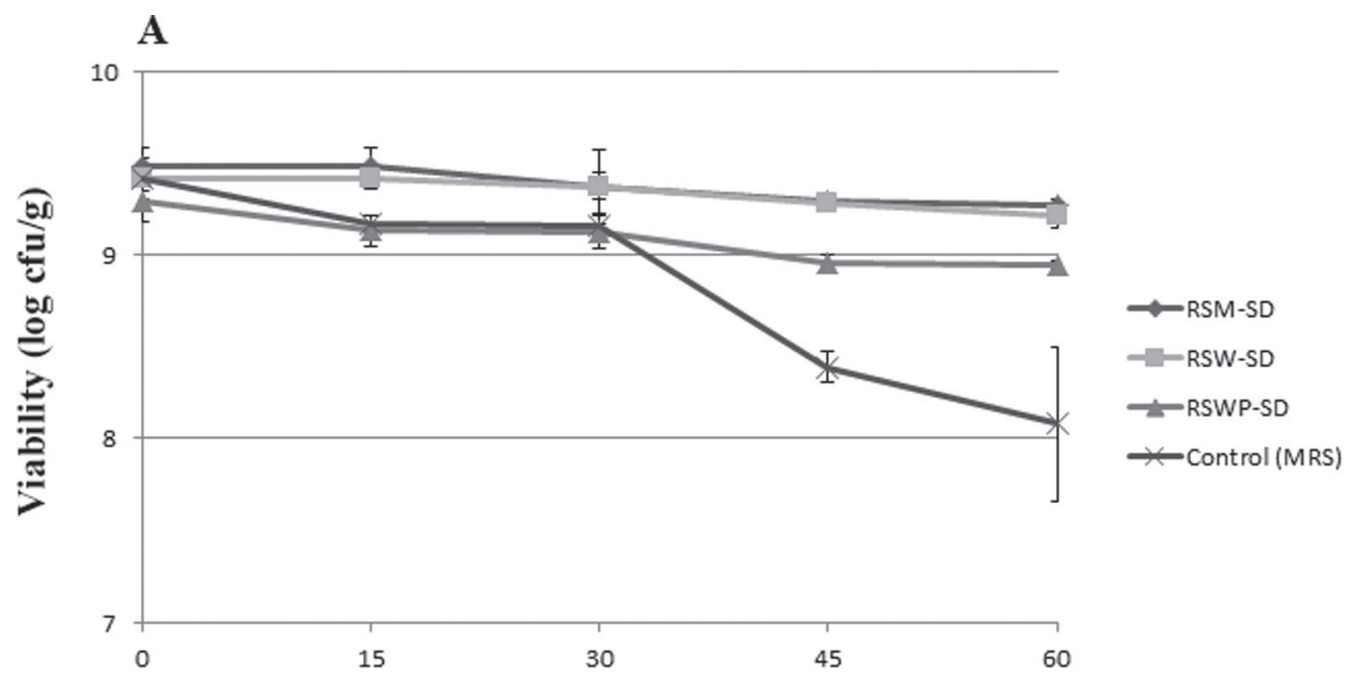

B

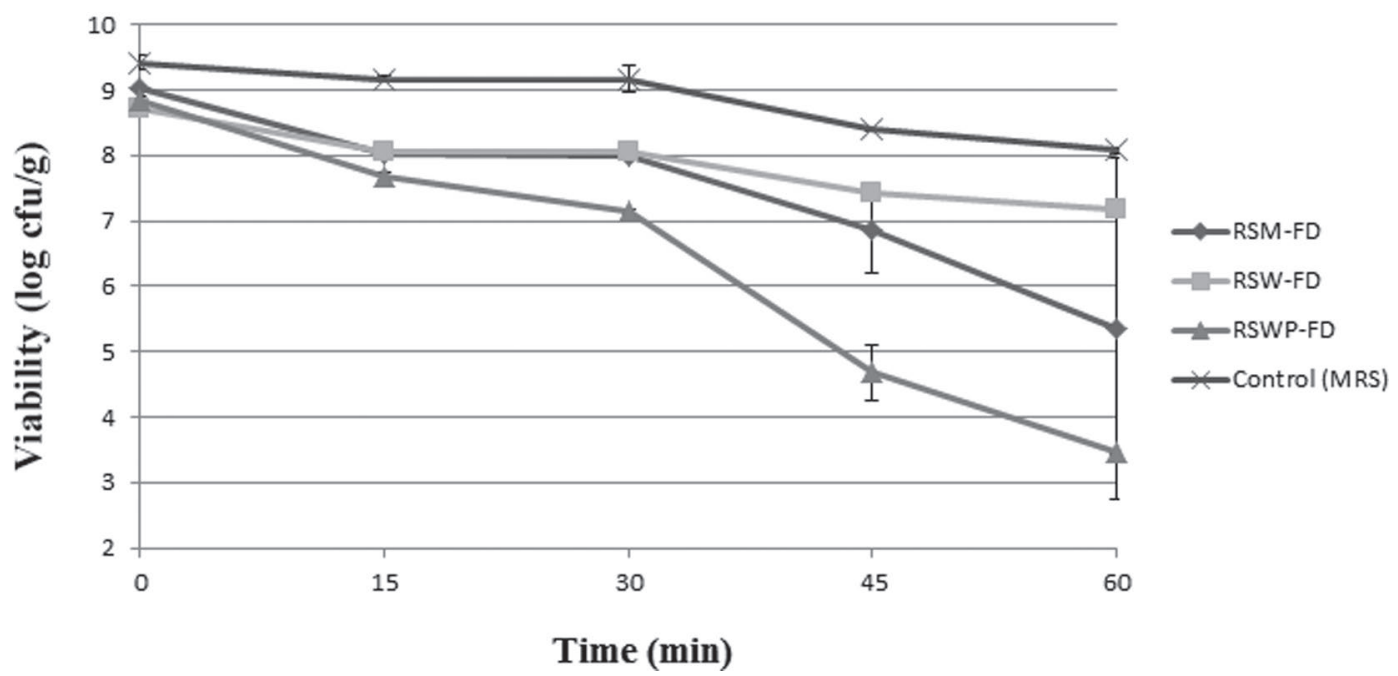

Figure 3. Acid stress during $60 \mathrm{~min}$ of freeze-dried and spray-dried cultures in different medium in triplicate. SD = spray drying; FD = freeze drying. (A) Spray drying samples, (B) freeze drying samples. RSM = reconstituted skim milk powder; RSW = reconstituted sweet whey powder; RSWP = reconstituted sweet whey permeate powder; MRS = de Man, Rogosa, and Sharpe. Error bars represent SE.

\section{DISCUSSION}

\section{Effects of Freeze Drying and Spray Drying on Survival Rate}

Freeze drying and spray drying have both been considered for the preservation and storage of bacteria for industrial applications (Zamora et al., 2006; Reddy et al., 2009; Schuck et al., 2013; Soukoulis et al., 2014; Kandil and El Soda, 2015; Shokri et al., 2015; Utami et al., 2016). Starter cultures for industrial applications require maintaining high viabilities and biological activity during both drying and storage processes
(Strasser et al., 2009). In this study, all L. plantarum samples evaluated showed high viability over a 60-d storage period for industrial applications, although the cell concentrations in freeze-dried samples were lower than spray-dried samples. According to Morgan et al. (2006) cell concentration $\left(>1 \times 10^{8}\right.$ cells $\left.\cdot \mathrm{mL}^{-1}\right)$ has been determined as the higher initial cell concentration that allows the longer viable survival of cells within the freeze-dried sample during the storage. Possibly, the lower survival rate of freeze-dried cells can be explained by the slow freezing applied before the freeze-drying process, which may result in a greater ice crystal formation. Ice crystal formation during the 
initial freezing step of freeze drying can lead to damage in the plasmatic membrane, resulting in loss of cell viability. Consequently, the DNA can also be affected (Castro et al., 1997). Lievense et al. (1994) considered the plasmatic membrane as the principal site of lethal damage after freeze drying.

In this study, we reported that freeze-dried and spray-dried samples in RSM and RSW showed a better survival rate during the storage period than freezedried and spray-dried samples in RSWP. According to Maciel et al. (2014), dairy matrices are beneficial for encapsulation and cell viability protection for lactic acid and probiotic bacteria in a spray-drying process. This protection may be related to the presence of milk proteins and lactose in these matrices. Accordingly, sweet whey permeate, which does not have significant amounts of protein, resulted in lower survival rates of bacteria in our study. Ananta et al. (2005) and Zamora et al. (2006) suggested that RSM at a concentration of $20 \%$ would be the optimal solid content to ensure a high residual viability of different strains of LAB. In this study, we used a carrier medium with $20 \%$ concentration (wt/wt), which maintained the viability of spray-dried samples. The drying medium's composition influenced bacteria survival. It is very important to define the best drying carrier medium composition and concentration. According to Fu and Chen (2011), the effect of the carrier medium's composition on cell
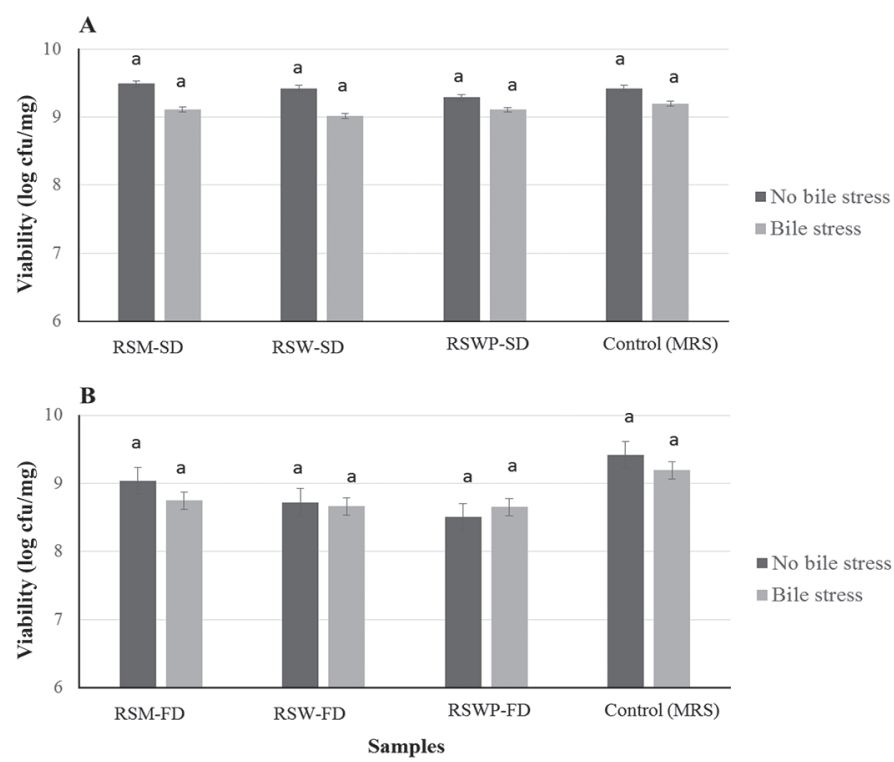

Figure 4. Bile salt tolerance of Lactobacillus plantarum in triplicate. $\mathrm{SD}=$ spray drying; FD = freeze drying. (A) Spray-dried cells, (B) freeze-dried cells. Different letters indicate a significant difference between bacteria populations $(P<0.01) . \mathrm{RSM}=$ reconstituted skim milk powder; RSW = reconstituted sweet whey powder; RSWP = reconstituted sweet whey permeate powder; MRS = de Man, Rogosa, and Sharpe. Error bars represent SE.
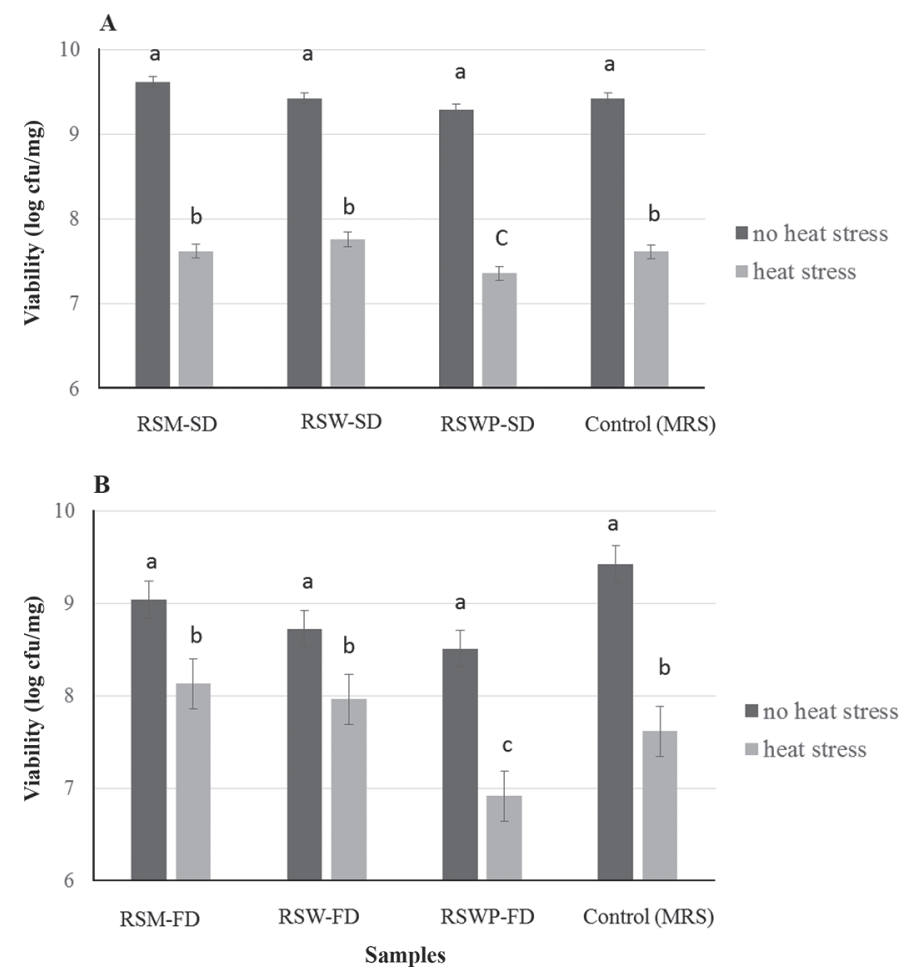

Figure 5. Lactobacillus plantarum subjected to heat stress conditions in triplicate. $\mathrm{SD}=$ spray drying; $\mathrm{FD}=$ freeze drying. $(\mathrm{A})$ Spray-dried cells, (B) freeze-dried cells. Different letters indicate a significant difference between bacteria populations $(P<0.01)$. RSM $=$ reconstituted skim milk powder; RSW = reconstituted sweet whey powder; RSWP = reconstituted sweet whey permeate powder; MRS = de Man, Rogosa, and Sharpe. Error bars represent SE.

survival during the drying process has an influence on the metabolic flux of microbial cells.

Our results differ from other authors who report a lower survival rate of spray-dried cells (To and Etzel, 1997). According to Santivarangkna et al. (2008), outlet air temperature can be the major drying parameter affecting the viability of spray-dried starter cultures. However, in our study, the parameters used in spraydrying are different from those of To and Etzel (1997) who used higher inlet $\left(220^{\circ} \mathrm{C}\right)$ and outlet temperatures $\left(70,75,80\right.$, and $\left.90^{\circ} \mathrm{C}\right)$. The different outlet-air temperatures used by To and Etzel (1997) influenced the survival rate of the microorganisms, whose residual viability increased with the decrease of outlet-air temperature. The use of lower temperatures in our study enabled us to maintain powders in a glassy state, allowing for a better conservation of L. plantarum compared with other studies.

\section{Water Profile in Powders (Spray Drying)}

Controlling the spray dryer parameters to obtain a relative humidity constant of outlet-air allowed for low 
water activity in the final product explains the maintained survival rate of $L$. plantarum throughout storage time. According to Schuck et al. (2005), water content and water activity optimization in dairy powders allows control over powder composition and properties, which in turn makes it possible to obtain a dehydrated product with lower sticking and clumping, favoring a glassy state.

In these conditions, the powder had a good quality with low water activity $(0.12-0.17)$ and low moisture (3.4-3.9\%). According to Shokri et al. (2015) the outlet-air temperature in different parts of a spray dryer should not be above $75^{\circ} \mathrm{C}$ to avoid serious cell damage. In addition, the temperature should not fall below $60^{\circ} \mathrm{C}$, because lower temperatures could result in higher moisture in the powder (up to 7\%). The authors suggested that the best powder moisture content is 4 to $7 \%$. These data are similar to the results obtained in this study. Water activity has been recognized as one of the primary factors that influences thermal resistance of bacteria in low-moisture foods. Hypothetically, the drying of bacterial cells can reduce the molecular mobility and help stabilize ribosomal units against irreversible damage caused by thermal energy in low-moisture environments (Syamaladevi et al., 2016). Moreover, the fast feed rate $\left(30 \mathrm{~mL} \cdot \mathrm{min}^{-1}\right)$ used in this study shortened the residence time between the hot air and the material, minimizing the damages of thermal inactivation.

\section{Effect of Freeze Drying and Spray Drying on Acidifying Activity}

The ability to acidify milk is the most important biological property for LAB used as starters in cheese making. According to Beresford et al. (2001), a good strain candidate for a starter culture should produce sufficient acid to reduce the $\mathrm{pH}$ of the milk to below 5.3 after $6 \mathrm{~h}$ of incubation in milk at $30^{\circ} \mathrm{C}$.

All the L. plantarum samples tested here were able to reduce the $\mathrm{pH}$ to below 6.0 after $6 \mathrm{~h}$ of incubation. However, after $24 \mathrm{~h}$, the spray-dried samples reduced the $\mathrm{pH}$ even more than the freeze-dried samples during same period of evaluation. The spray-dried cells were able to adapt better to RSM $10 \%$, probably because these cells had been subject to fewer injuries during the drying process, which in turn allowed them a better technological performance, although the survival rates after drying in time 0 were similar across the samples. The ability to acidify milk using spray-dried cells in all samples remained the same, so in this case any of the carrier mediums can be used as an adjunct culture to preserve L. plantarum cells for industrial application.

\section{Effect of Freeze Drying and Spray Drying on Stress Tolerance}

Acid and bile tolerance are important considerations for probiotics and constitute a limit to their efficacy. Acid tolerance is required for bacteria to survive passage through the stomach; bile tolerance is required for survival in the small intestine (Madhu et al., 2011; Shokri et al., 2015; Utami et al., 2016). The high acid and bile tolerance shown by the spray-dried samples suggests spray-drying could be a highly viable alternative for preserving probiotics in industrial food applications. According to Paéz et al. (2012), spray drying could also be used to enhance cell functionality. Similar results were found by Reddy et al. (2009) where $L$. plantarum CFR 2158 maintained 100\% viability when microencapsulated by spray drying with skim milk and exposing it to $\mathrm{pH} 2.0$ for $4 \mathrm{~h}$.

Additionally, the cells cultured in MRS broth showed better resistance to acid conditions than freeze-dried samples. This can be explained by cell injuries caused during the freeze-drying process that affected their physiological characteristics as well as their acidifying activity. Therefore, under acid conditions, the carrier medium and the drying method influenced the results.

In addition, the samples subjected to heat stress conditions decreased to less than 2 log cycles after 10 min. The thermal resistance of the L. plantarum strain studied was confirmed, which also explains the better survival rate over storage time after spray-drying. The L. plantarum cells cultured in MRS showed higher thermal resistance than the RSWP samples. In this case, the influence of the carrier medium was greater than the influence of the drying method. It has been reported that survival rate reduction and stress response of some starter cultures is dependent on species, method of preservation, and carrier medium (To and Etzel, 1997; Dijkstra et al., 2014).

\section{CONCLUSIONS}

Spray drying and freeze drying of L. plantarum cells were investigated with different dairy fractions as carriers. Surprisingly, spray drying was less damaging than freeze drying in relation to the technological performance for skim milk and probiotic properties of the cells. However, it is still necessary to evaluate the parameters of both processes to optimize conditions for cell viability and biological activity in relation to growth and protection media, conduction of proceedings, storage, and rehydration to obtain a better comparison of the 2 techniques. As spray drying is far more cost-effective than freeze drying, this study opens new prospects for 
the sustainable production of robust starters adapted to cheese making.

\section{ACKNOWLEDGMENTS}

The authors acknowledge the financial support from the following Brazilian agencies: Fundação de Amparo à Pesquisa do Estado de Minas Gerais (Fapemig, Belo Horizonte), Coordenacão de Aperfeiçoamento de Pessoal de Nível Superior (CAPES, Brasília), and Conselho Nacional de Desenvolvimento Científico e Tecnológico (CNPq, Brasília).

\section{REFERENCES}

Ananta, E., M. Volkert, and D. Knorr. 2005. Cellular injuries and storage stability of spray-dried Lactobacillus rhamnosus GG. Int. Dairy J. 15:399-409. https://doi.org/10.1016/j.idairyj.2004.08.004.

Beresford, T. P., N. A. Fitzsimons, N. L. Brennan, and T. M. Cogan. 2001. Recent advances in cheese microbiology. Int. Dairy J. 11:259-274. https://doi.org/10.1016/S0958-6946(01)00056-5.

Carvalho, A. S., J. Silva, P. Ho, P. Teixeira, F. X. Malcata, and P. Gibbs. 2003. Effect of various growth media upon survival during storage of freeze-dried Enterococcus faecalis and Enterococcus durans. J. Appl. Microbiol. 94:947-952. https://doi.org/10.1046/ j.1365-2672.2003.01853.x.

Carvalho, A. S., J. Silva, P. Ho, P. Teixeira, F. X. Malcata, and P. Gibbs. 2004a. Effects of various sugars added to growth and drying media upon thermotolerance and survival throughout storage of freeze-dried Lactobacillus delbrueckii ssp. bulgaricus. Biotechnol. Prog. 20:248-254. https://doi.org/10.1021/bp034165y.

Carvalho, A. S., J. Silva, P. Ho, P. Teixeira, F. X. Malcata, and P. Gibbs. 2004b. Relevant factors for the preparation of freezedried lactic acid bacteria. Int. Dairy J. 14:835-847. https://doi. org/10.1016/j.idairyj.2004.02.001.

Castro, H. P., P. M. Teixeira, and R. Kirby. 1997. Evidence of membrane damage in Lactobacillus bulgaricus following freeze drying. J. Appl. Microbiol. 82:87-94. https://doi.org/10.1111/j.1365-2672.1997. tb03301.x.

Castro, R. D., L. Oliveira, F. Sant, L. Luiz, S. Sandes, C. Silva, A. Silva, A. Nunes, C. Penna, and M. Souza. 2016. Lactic acid microbiota identification in water, raw milk, endogenous starter culture, and fresh Minas artisanal cheese from the Campo das Vertentes region of Brazil during the dry and rainy seasons. J. Dairy Sci. 99:6086-6096. https://doi.org/10.3168/jds.2015-10579.

de Freitas, R., V. Chuat, M. N. Madec, L. A. Nero, A. Thierry, F. Valence, and A. F. Carvalho. 2015. Biodiversity of dairy Propionibacterium isolated from dairy farms in Minas Gerais, Brazil. Int. J. Food Microbiol. 203:70-77. https://doi.org/10.1016/j. ijfoodmicro.2015.03.006.

Dijkstra, A. R., M. C. Setyawati, J. R. Bayjanov, W. Alkema, S. A. F. T. van Hijum, P. A. Bron, and J. Hugenholtz. 2014. Diversity in robustness of Lactococcus lactis strains during heat stress, oxidative stress, and spray drying stress. Appl. Environ. Microbiol. 80:603-611. https://doi.org/10.1128/AEM.03434-13.

FAO/WHO. 2001. Probiotics in food: Health and nutritional properties and guidelines for evaluation. Food Nutr. Pap. 85:71. https:// doi.org/10.1201/9781420009613.ch16.

Fu, N., and X. D. Chen. 2011. Towards a maximal cell survival in convective thermal drying processes. Food Res. Int. 44:1127-1149. https://doi.org/10.1016/j.foodres.2011.03.053.

Huang, S., C. Cauty, A. Dolivet, Y. Le Loir, X. D. Chen, P. Schuck, G. Jan, and R. Jeantet. 2016. Double use of highly concentrated sweet whey to improve the biomass production and viability of spraydried probiotic bacteria. J. Funct. Foods 23:453-463. https://doi. org/10.1016/j.jff.2016.02.050.
Huang, S., and X. D. Chen. 2013. Significant effect of Ca2+ on improving the heat resistance of lactic acid bacteria. FEMS Microbiol. Lett. 344:31-38. https://doi.org/10.1111/1574-6968.12151.

Huang, S., Y. Yang, N. Fu, Q. Qin, L. Zhang, and X. D. Chen. 2014. Calcium-aggregated milk: A potential new option for improving the viability of lactic acid bacteria under heat stress. Food Bioproc. Techol. 7:3147-3155. https://doi.org/10.1007/s11947-0141331-9.

Kandil, S., and M. El Soda. 2015. Influence of freezing and freeze drying on intracellular enzymatic activity and autolytic properties of some lactic acid bacterial strains. Adv. Microbiol. 5:371-382.

Leverrier, P., D. Dimova, V. Pichereau, Y. Auffray, P. Boyaval, and G. Jan. 2003. Susceptibility and adaptive response to bile salts in Propionibacterium freudenreichii: Physiological and proteomic analysis. Appl. Environ. Microbiol. 69:3809-3818. https://doi. org/10.1128/AEM.69.7.3809.

Lievense, L. C., M. A. M. Verbreek, A. Noomen, and K. van't Riet. 1994. Mechanism of dehydration inactivation of Lactobacillus plantarum. Appl. Microbiol. Biotechnol. 41:90-94. https://doi. org/10.1007/BF00166087.

Maciel, G. M., K. S. Chaves, C. R. F. Grosso, and M. L. Gigante. 2014. Microencapsulation of Lactobacillus acidophilus La-5 by spray-drying using sweet whey and skim milk as encapsulating materials. J. Dairy Sci. 97:1991-1998. https://doi.org/10.3168/jds.2013-7463.

Madhu, A. N., S. P. Awasthi, K. B. P. K. Reddy, and S. G. Prapulla. 2011. Impact of freeze and spray drying on the retention of probiotic properties of Lactobacillus fermentum: An in vitro evaluation model. Int. J. Microbiol. Res. 2:243-251.

Morgan, C. A., N. Herman, P. A. White, and G. Vesey. 2006. Preservation of micro-organisms by drying; a review. J. Microbiol. Methods 66:183-193. https://doi.org/10.1016/j.mimet.2006.02.017.

Paéz, R., L. Lavari, G. Vinderola, G. Audero, A. Cuatrin, N. Zaritzky, and J. Reinheimer. 2012. Effect of heat treatment and spray drying on lactobacilli viability and resistance to simulated gastrointestinal digestion. Food Res. Int. 48:748-754. https://doi.org/10.1016/j. foodres.2012.06.018.

Peighambardoust, S. H., A. Golshan Tafti, and J. Hesari. 2011. Application of spray drying for preservation of lactic acid starter cultures: A review. Trends Food Sci. Technol. 22:215-224. https:// doi.org/10.1016/j.tifs.2011.01.009.

Randazzo, C. L., C. Caggia, and E. Neviani. 2009. Application of molecular approaches to study lactic acid bacteria in artisanal cheeses. J. Microbiol. Methods 78:1-9. https://doi.org/10.1016/j. mimet.2009.04.001.

Randazzo, C. L., S. De Luca, A. Todaro, C. Restuccia, C. M. Lanza, G. Spagna, and C. Caggia. 2007. Preliminary characterization of wild lactic acid bacteria and their abilities to produce flavour compounds in ripened model cheese system. J. Appl. Microbiol. 103:427-435. https://doi.org/10.1111/j.1365-2672.2006.03261.x.

Rathnayaka, R. M. U. S. K. 2013. Effect of freeze-drying on viability and probiotic properties of a mixture of probiotic bacteria. ARPN J. Sci. Technol. 3:1074-1078.

Reddy, K. B. P. K., A. N. Madhu, and S. G. Prapulla. 2009. Comparative survival and evaluation of functional probiotic properties of spray-dried lactic acid bacteria. Int. J. Dairy Technol. 62:240-248. https://doi.org/10.1111/j.1471-0307.2009.00480.x.

Santivarangkna, C., U. Kulozik, and P. Foerst. 2007. Alternative drying processes for the industrial preservation of lactic acid starter cultures. Biotechnol. Prog. 23:302-315.

Santivarangkna, C., U. Kulozik, and P. Foerst. 2008. Inactivation mechanisms of lactic acid starter cultures preserved by drying processes. J. Appl. Microbiol. 105:1-13. https://doi.org/10.1111/ j.1365-2672.2008.03744.x.

Schuck, P., A. Dolivet, and R. Jeantet. 2012. Determination of dry matter and total dry matter (Chapter 2). Pages 45-57 in Analytical Methods for Food and Dairy Powders. Wiley, Hoboken, NJ.

Schuck, P., A. Dolivet, S. Méjean, C. Hervé, and R. Jeantet. 2013 Spray drying of dairy bacteria: New opportunities to improve the viability of bacteria powders. Int. Dairy J. 31:12-17. https://doi. org/10.1016/j.idairyj.2012.01.006. 
Schuck, P., S. Méjean, A. Dolivet, and R. Jeantet. 2005. Thermohygrometric sensor: A tool for optimizing the spray drying process. Innov. Food Sci. Emerg. Technol. 6:45-50. https://doi.org/10.1016/j. ifset.2004.10.001.

Shokri, Z., M. Fazeli, M. Ardjmand, S. Mousavi, and K. Gilani. 2015. Factors affecting viability of Bifidobacterium bifidum during spray drying. DARU J. Pharm. Sci. 23:7. https://doi.org/10.1186/ s40199-014-0088-z.

Silva, J., R. Freixo, P. Gibbs, and P. Teixeira. 2011. Spray-drying for the production of dried cultures. Int. J. Dairy Technol. 64:321-335. https://doi.org/10.1111/j.1471-0307.2011.00677.x.

Soukoulis, C., S. Behboudi-Jobbehdar, L. Yonekura, C. Parmenter, and I. Fisk. 2014. Impact of milk protein type on the viability and storage stability of microencapsulated Lactobacillus acidophilus NCIMB 701748 using spray drying. Food Bioproc. Techol. 7:12551268. https://doi.org/10.1007/s11947-013-1120-x.

Strasser, S., M. Neureiter, M. Geppl, R. Braun, and H. Danner. 2009 Influence of lyophilization, fluidized bed drying, addition of protectants, and storage on the viability of lactic acid bacteria. J. Appl. Microbiol. 107:167-177. https://doi.org/10.1111/j.13652672.2009.04192.x.

Syamaladevi, R. M., J. Tang, R. Villa-Rojas, S. Sablani, B. Carter, and G. Campbell. 2016. Influence of water activity on ther- mal resistance of microorganisms in low-moisture foods: A review. Compr. Rev. Food Sci. Food Saf. 15:353-370. https://doi. org/10.1111/1541-4337.12190.

Terzic-Vidojevic, A., S. Mihajlovic, G. Uzelac, K. Veljovic, M. Tolinacki, M. Nikolic, L. Topisirovic, and M. Kojic. 2014. Characterization of lactic acid bacteria isolated from artisanal Travnik young cheeses, sweet creams and sweet kajmaks over four seasons. Food Microbiol. 39:27-38. https://doi.org/10.1016/j.fm.2013.10.011.

To, B. C. S., and M. R. Etzel. 1997. Spray drying, freeze drying, or freezing of three different lactic acid bacteria species. J. Food Sci 62:576-579.

Utami, T., E. Harmayani, and E. S. Rahayu. 2016. Survival of Lactobacillus plantarum Dad 13 during spray drying and its application for yoghurt fermentation. Int. Res. J. Biol. Sci. 5:16-22.

Van Hoorde, K., T. Verstraete, P. Vandamme, and G. Huys. 2008 Diversity of lactic acid bacteria in two Flemish artisan raw milk Gouda-type cheeses. Food Microbiol. 25:929-935. https://doi. org/10.1016/j.fm.2008.06.006.

Zamora, L. M., C. Carretero, and D. Parés. 2006. Comparative survival rates of lactic acid bacteria isolated from blood, following spray-drying and freeze-drying. Food Sci. Technol. (Campinas) 12:77-84. https://doi.org/10.1177/1082013206062443. 